\title{
Growing Processing Freestone Peaches in California: An Overview
}

MAXWELL NORTON, University of California Cooperative Extension Farm Advisor, Merced County; ROGER DUNCAN, University of California Cooperative Extension Farm Advisor, Stanislaus County.

California produces most of the nation's processing freestone peaches. Other major peach producers worldwide are China, Greece, Spain, and Chile. All of California's processing freestone peach acreage is located in the San Joaquin Valley. As of 2008, the counties with the most acreage were Stanislaus and Merced, with lesser acreages in Fresno, San Joaquin, Madera, Kings, and Tulare Counties. In the northern San Joaquin Valley it is common for entire orchard blocks to be dedicated to processing use. Further south in the valley, freestone peaches that have been planted for shipment to fresh fruit markets may also be diverted for processing in some years. Packing sheds for the fresh fruit market may also pull fruit that is too small or has cosmetic defects and divert it to processors.

Most processing freestones are frozen, using the block method or the instant quick freeze method. The next largest use is for canning. Lesser amounts are dried or are used in frozen fruit cups. Cull peaches may be used for puree or juice. Because of the "melting-flesh" nature of freestone peaches, which makes them particularly desirable as a dessert fruit, they do not hold their shape in the can as well as clingstone peaches and their pack-out rate (the number of cans per pound of peaches) is less than that for clingstones.

\section{PLANNING THE ORCHARD}

\section{Potential for Profit}

During an orchard's initial development, its yield potential is directly related to how quickly the trees fill the space in the orchard. At maturity, though, the yield potential for a high-density orchard is the same as that for a conventionally planted system. High-density peach orchards can produce higher yields sooner than conventional orchards, but their initial planting costs are higher because the grower has to plant more trees per acre. Highdensity orchards can yield 2 to 3 tons of fruit per acre in their second season; conventionally spaced orchards often see their first harvest three years after planting, with a yield of approximately 6 tons per acre for a well-managed 
block. Potential yields for subsequent years, regardless of spacing method, may be 12 tons for the fourth year, 15 tons for the fifth, 18 tons for the sixth, and 20 or more tons for every year thereafter. From 2001 to 2005, average returns to freestone processing peaches in California were $\$ 237$ per ton. Most processor contracts include significant bonuses and penalties related to fruit quality. Peach orchards are generally replanted every 15 to 18 years.

\section{Production Costs}

The greatest production costs for a freestone peach grower are for pruning, thinning, pest management, and harvesting. The University of California Cooperative Extension has developed cost studies that show generalized production costs for fresh market peaches, and the cost studies for cling peaches can be used as a close approximation of the costs to grow processing freestones. The cost studies are available at UC Cooperative Extension county offices and some financial institutions and are available free on the Internet at the UC Davis Department of Agricultural and Resource Economics website,

http://coststudies.ucdavis.edu.

\section{Climate}

Peaches require adequate winter chilling (approximately 750 to 900 hours of temperatures below $45^{\circ} \mathrm{F}$, depending on the variety) for normal flowering and fruit set. Bloom normally occurs in early March. Hot, dry conditions during bloom can result in a shortened bloom period and a reduced crop. Wet weather during bloom can reduce set or induce blossoming and subsequent fruit disease. Growers get the best yield and quality when the growing season has been warm and dry. Spring frost is less of a problem for processing peaches than for earlier-blooming crops such as almonds and fresh-market peaches, but growers who plant in frost-prone areas may have to carry the extra expense of frost protection.

\section{SuItABle SoILS}

Peaches are most productive on well-drained, uniform, sandy loam soils. Optimal soil textures range from sand to loam. Peaches can also do well on clay loam soils, but growers may have trouble getting good fruit size and will have to keep a close eye on irrigation. Although county soil surveys do provide information on local soils, they may not show sufficient detail to help the grower make a good planting decision. Use a backhoe to dig several holes on the prospective orchard property in areas where differences in soil type seem likely. Growers who are not familiar with soil evaluation can contact the local county UC Cooperative Extension office for assistance.

Look for anything that might restrict water movement and root growth, such as clay pans, hardpans, silt pans, stratification, and high water tables. Soil chemical analysis gives clues to problems with $\mathrm{pH}$, salinity, and toxicity from boron (B), sodium $(\mathrm{Na})$, and chloride $\left(\mathrm{Cl}^{-}\right)$. Correction of soil problems before planting is more effective and less expensive than trying to correct problems after the orchard is established. Consider using alternate rootstocks in areas with potential $\mathrm{pH}$ or salt problems.

\section{ESTABLISHING THE ORCHARD}

Good planning is essential to the efficient operation and ultimate profitability of an orchard. Before planting, it is important that the grower install an irrigation system, level the land to promote uniform water distribution in flood-irrigated orchards, deep till, rip, or backhoe to destroy or mix impervious layers in the soil profile, fumigate based on nematode samples and orchard history, and choose the proper peach variety and rootstock. Allow at least 1 year of lead-time to complete these operations before planting.

There is a wide range of tree and row spacings in use today. The general trend is toward higher densities and shorter trees that are less reliant on ladders for harvesting and thinning. A common spacing in conventionally planted orchards is 16 to 20 feet apart for trees in the row and 18 to 22 feet between rows. Tree spacing in high-density orchards is typically 6 to 8 feet between trees in the row and 16 to 18 feet between rows. Higher-density plantings may require the use of modified farm equipment, and the trees may need to be trained to accommodate mechanical harvesters.

\section{IRRIGATION}

Like other tree crop plantings, a mature peach orchard with vegetation between the rows will use about 40 acre-inches of water per acre per year, including rainfall. Peak water use in midsummer is about 0.3 inch per day. With a safety factor included for exceptionally hot, windy weather and the potential of interrupted water supplies, the irrigation system should be designed to deliver at least 0.5 inch per day.

The type of irrigation system a grower uses is not as important as how well it is designed 
and managed. The system should distribute the water uniformly to each tree. The choice of which system to use depends on the availability and cost of water, the type and depth of soil, the amount of land leveling needed, and any special management problems that may apply.

A large proportion of recently developed peach orchards use two drip hoses per row with in-line drippers that are sturdy enough to tolerate being walked on by laborers. Planting trees on a berm (a raised area of soil along the tree row) and flooding the middles is another common method; it usually involves a lower initial cost and is cheaper to operate and maintain than drip. Impact sprinklers are rarely used. Low-volume microsprinklers and microjets may increase humidity in the orchard, and that can lead to disease problems. These sprinklers may also be poorly suited to the large amount of foot traffic around trees during pruning, thinning, and harvesting. Low-volume irrigation systems have the advantage that they can also be used to deliver nitrogen, potassium, and other fertilizers to trees.

\section{VARIETIES}

All peach varieties are of the genus and species Prunus persica. The flowers are self-fertile, so bees are not needed to produce commercial crops. Angelus, Fairtime, and Z Ladys are common processing varieties. Fay Elberta is also used, but to a lesser degree. Two other varietal categories are the "gem" and "late-gem" types. Growers should consult with a processor representative to see which fruit varieties the processor is most likely to buy.

A common strategy is to plant a range of varieties that ripen one after the other over a long period as a way to reduce peak labor demands. Peaches can have a slight tendency toward alternate bearing (a heavy crop followed by a light crop the next year) when the crop size is not controlled by pruning or thinning. New varieties have recently been introduced by peach growers, independent plant breeders, and the University of California. For information on new varieties, contact your local UC Cooperative Extension Farm Advisor.

\section{ROOTSTOCKS}

The most commonly used rootstocks in California are Lovell and Nemaguard. Some nurseries use proprietary rootstocks as well. The grower's choice of rootstock will depend on the orchard's soil type and continuing problems such as high $\mathrm{pH}$, salinity, soil pathogens, and parasitic nematodes. Almost all rootstocks currently in use are considered to be vigorous and will produce a full-sized tree. Nemaguard is resistant to the most common strains of root knot nematode but is susceptible to ring nematode, which is associated with bacterial canker complex, a serious disease of peach trees planted on sandy soils. Some new orchards are being planted on new size-reducing rootstocks that will produce trees 80 to 90 percent of the size of Nemaguard-grown trees.

\section{EQUIPMENT}

The equipment commonly needed for a 40 -acre peach orchard might include a 40 - to 60-horsepower wheel tractor, a 9-foot, offset-wheel disc or mower/ brush shredder, a three-point push scraper, a weed sprayer, a furrower (if the orchard is furrowirrigated), three-point forks for moving harvest bins, a hydraulic pull scraper, an orchard sprayer, a forklift, and several bin trailers.

\section{MANAGING THE ORCHARD}

\section{Training AND PRUNING}

Train the peach trees to provide a strong framework capable of supporting a large crop and accommodating harvest equipment. Peach trees need to be pruned every year to maintain consistent, uniform yields and good fruit size. Most trees benefit from having a rope or wire strung around the scaffold branches to prevent breakage from heavy crops.

\section{Orchard Floor Management}

Weed management in peaches is similar to that used for other tree crops. Common management systems usually involve weed control with herbicides around the base of the tree or along the berm, combined with discing or mowing the row centers. The growing of cover crops between the tree rows is becoming more common.

\section{FERTILIZING}

Depending on tree vigor, processing peaches are commonly fertilized at a rate of 50 to 100 pounds of actual nitrogen $(\mathrm{N})$ per acre per year, applied during the growing season. Other than nitrogen, zinc $(\mathrm{Zn})$ is generally the element most likely to become deficient on sandy soils, and foliar sprays of zinc are commonly applied. Peaches make heavy use of potassium $(\mathrm{K})$, and it may become deficient 
in soils that are inherently low in potassium.

Potassium deficiency is best corrected with massive soil applications every 3 to 5 years or with annual soil applications of lower, maintenance rates. Growers can apply it as potassium chloride if the soil is sandy and the chloride can be leached. Potassium sulfate is also used and does not entail the risk of chloride toxicity.

\section{THINNING}

The Central Valley's climate is excellent for heavy production of peaches, but an orchard's profitability is based on the grower's ability to consistently produce moderate crops of good-sized fruit. Excessive crops on individual trees generally result in smaller, lower-valued fruit. Growers must use a combination of pruning and fruit thinning to regulate crop and fruit size. Currently, thinning is an operation performed by hand and at considerable cost. UC specialists are experimenting with mechanical and chemical thinning techniques that would reduce that cost.

\section{PEST MANAGEMENT}

Insect pests that require annual treatment include peach twig borer (PTB) and oriental fruit moth (OFM). Other insect pests such as San Jose scale, oblique-banded leafroller (OBLR), omnivorous leafroller (OLR), stink bug, lygus bug, calocoris, katydids, mites, and leaf-footed plant bug occasionally need treatment and should be regularly monitored. Insect pests can vary by region; check with local UC Cooperative Extension Farm Advisors or pest control advisers to learn what pests are common in your area.

Warm, wet weather during bloom time can lead to blossom brown rot, which can cause major economic losses. Blossom brown rot can be followed by fruit brown rot as the fruit ripen, especially if there is summer rainfall. Shot hole can damage buds, leaves, twigs, and fruit. Peach leaf curl (PLC) must be controlled during the dormant season. Other lesscommon diseases that can damage fruit are powdery mildew and rust. Diseases that can damage the tree itself include bacterial canker, Armillaria root rot, and Phytophthora crown and root rot.

Nematodes-microscopic worms that feed in and on the peach tree's roots-are associated with sandy soils and locations that have previously been planted to stone fruit. The best control strategy for nematodes is to completely remove old roots, backhoe the tree sites, do preplant fumigation, and make use of nematode-tolerant rootstocks.
Several excellent UC ANR publications that cover pest management practices in detail are available from local UC Cooperative Extension county offices or from the UC ANR online catalog, http://anrcatalog.ucdavis.edu. For a good model of a pest management program, obtain a copy of Seasonal Guide to Environmentally Responsible Pest Management Practices in Peaches and Nectarines (ANR Publication 21625). Also, consult the continuously updated UC IPM Pest Management Guidelines for Peaches. Detailed information on managing the pests and diseases of canning peaches can also be found in the book Integrated Pest Management for Stone Fruits (ANR Publication 3389).

\section{HARVESTING}

Grade and size standards depend on how the fruit is to be utilized. In all grading programs, worms and rots are cause for culling. Higher soluble solids or maturity is generally desirable, up to the point where fruit softening and bruising would occur. With fruit to be used for processing, skin color is not a determinant of maturity. The most commonly used indicator is flesh color, and to a lesser degree, soluble solids content.

Since all of the fruit on a tree does not ripen uniformly, a grower often has to do two or three pickings based on fruit color. This is especially common in orchards grown on sandier soils. Finding sufficient labor for the harvest can be a significant challenge in some years. In orchards that use mechanical harvesting, the grower may still want to do a first picking by hand based on fruit color and follow that later on with a machine harvest when the rest of the fruit is mature. In-field hand-sorting of small or damaged fruit is a common practice. Successful mechanical harvesting is predicated on the use of machines that are well designed, well maintained, and carefully operated. Harvesters usually are operated in the early morning hours when fruit temperatures are low and the fruit are less prone to injury.

\section{MARKETING}

Processing freestone peaches are marketed to a processor, freezer, or dryer, usually under a multiyear contract. All of the fruit is processed within California. A list of processors is available from the California Freestone Peach Association (see contact information under Where to Get More Information). Talk to as many processing companies 
as possible and ask other growers about their reliability and reputation. Have a lawyer review any contract, which should detail the responsibilities and protections of all the parties involved. Quality and maturity standards as well as grading procedures should be set out in the agreement. Third-party graders are often employed and are usually paid for by the processor.

As of this writing there is no marketing order or "check-off" for processing freestones. Many growers are members of the California Freestone Peach Association, a bargaining association that negotiates with processors on behalf of its grower members.

\section{METRIC CONVERSIONS}

\begin{tabular}{|l|c|c|c|}
\hline English & Conversion factor for English to Metric & Conversion factor for Metric to English & Metric \\
\hline Area & $\times 0.4047$ & $\times 2.47$ & hectare (ha) \\
\hline acre $(\mathrm{ac})$ & $\times 0.454$ & $\times 2.205$ & kilogram (kg) \\
\hline Mass & & & \\
\hline pound $(\mathrm{lb})$ & ${ }^{\circ} \mathrm{C}=\left({ }^{\circ} \mathrm{F}-32\right) \div 1.8$ & ${ }^{\circ} \mathrm{F}=\left({ }^{\circ} \mathrm{C} \times 1.8\right)+32$ & Celsius $\left({ }^{\circ} \mathrm{C}\right)$ \\
\hline \begin{tabular}{l} 
Temperature \\
\hline Fahrenheit $\left({ }^{\circ} \mathrm{F}\right)$
\end{tabular}
\end{tabular}

\section{WHERE TO GET MORE INFORMATION}

University of California Cooperative Extension maintains an office in most California counties, with Farm Advisors who specialize in the crops grown in the county. You can contact them free of charge for information and assistance. A list of offices can be found at http://ucanr.org/ce.cfm. Prospective growers are urged to get information from UC before entering into a commercial peach growing enterprise. The University also publishes books, leaflets, and online materials on farming practices; see the online catalog at http://anrcatalog. ucdavis.edu, or contact your local UC Cooperative Extension county office.

The California Freestone Peach Association has representatives in all California peach-growing regions. Find them online at http://calpeach.com, or contact them by phone (916-925-9131) or by mail (2300 River Plaza Drive, Suite 110, Sacramento, CA 95833). 


\section{FOR MORE INFORMATION}

You will find related information in these titles and in other publications, slide sets, CD-ROMs, and videos from UC ANR:

Integrated Pest Management for Stone Fruits, Publication 3389

Peaches, Plums, and Nectarines: Growing and Handling for Fresh Market, Publication 3331

Seasonal Guide to Environmentally Responsible Pest Management Practices in Peaches and Nectarines, Publication 21625

UC IPM Pest Management Guidelines for Peaches, Publication 3454

To order or obtain ANR publications and other products, visit the ANR Communication Services online catalog at http://anrcatalog. ucdavis.edu or phone 1-800-994-8849. You can also place orders by mail or FAX, or request a printed catalog of our products from:

\section{University of California}

Agriculture and Natural Resources

Communication Services

6701 San Pablo Avenue, 2nd Floor

Oakland, California 94608-1239

Telephone: (800) 994-8849 or (510) 642-2431,

FAX: (510) 643-5470

e-mail inquiries: danrcs@ucdavis.edu

An electronic version of this publication is available on the ANR Communication Services website at http://anrcatalog.ucdavis.edu. Publication 8358

ISBN-13: 978-1-60107-611-3

\section{UEER}

REVIEWED This publication has been anonymously peer reviewed for technical accuracy by University of California scientists and other qualified professionals. This review process was managed by the ANR Associate Editor for Pomology, Viticulture, and Subtropical Horticulture.

(C) 2009 by The Regents of the University of California

Division of Agriculture and Natural Resources.

All rights reserved.
The University of California prohibits discrimination or harassment of any person on the basis of race, color, national origin, religion, sex, gender identity, pregnancy (including childbirth, and medical conditions related to pregnancy or childbirth), physical or mental disability, medical condition (cancer-related or genetic characteristics), ancestry, marital status, age, sexual orientation, citizenship, or service in the uniformed services (as defined by the Uniformed Services Employment and Reemployment Rights Act of 1994: service in the uniformed services includes membership, application for membership, performance of service, application for service, or obligation for service in the uniformed services) in any of its programs or activities.

University policy also prohibits reprisal or retaliation against any person in any of its programs or activities for making a complaint of discrimination or sexual harassment or for using or participating in the investigation or resolution process of any such complaint.

University policy is intended to be consistent with the provisions of applicable State and Federal laws.

Inquiries regarding the University's nondiscrimination policies may be directed to the Affirmative Action/Equal Opportunity Director, University of California, Agriculture and Natural Resources, 1111 Franklin Street, 6th Floor, Oakland, CA 94607, (510) 987-0096. For information about obtaining this publication, call (800) 994-8849. For downloading information, call (530) 754-3927.

pr-2/09-WJC/AZ 